discovery of evidence that gravitational waves from astrophysical systems have observable consequences provided the impetus for proposed gravity-wave detectors, such as the proposed Laser Interferometer Gravitational Wave Observatory (LIGO) in the United States, and the Franco-Italian detector Virgo. Both are huge interferometric systems designed to detect gravitational waves produced from astrophysical events as they wash over Earth.

Hewish, whose discovery earned him the Nobel prize in 1974, says that Taylor and

\section{IMAGE UNAVAILABLE FOR COPYRIGHT REASONS}

\section{Joseph Taylor and Russell Hulse: persistence rewarded.}

Hulse's prize should brighten the prospects for these expensive projects, which have fought for survival for years. LIGO's director Rochus Vogt of the California Institute of Technology says that the award is "an endorsement by the Nobel committee of the importance of gravity waves", and "will definitely help [LIGO] in the long run".

Meanwhile, Hulse himself switched to research on plasma fusion at Princeton soon after completing his thesis. One reason, he says, was the lack of long-term opportunities in astrophysics.

Philip Ball

\section{SSC faces last ditch challenge in Congress}

Washington. Three hotly disputed research programmes were each given full funding at a joint meeting last week designed to iron out differences between representatives of the US House of Representatives and Senate.

The conference agreement on the Energy and Water budget bill allowed $\$ 640$ million for the Superconducting Super Collider, $\$ 110$ million for the Integral Fast Reactor (IFR) programme and $\$ 36$ million for the $\mathrm{B}$ Factory to be built at Stanford, California. The outcome means a certain reprieve for the IFR, which the House had voted to shut down (see Nature 365, 99; 1993), and that work on the B factory can start immediately.

But the funding for the SSC was still set to face a last gasp challenge in the House earlier this week. SSC supporters were confident that the challenge would fail for procedural reasons, despite the unpopularity of the project in the House. The entire budget, comprising 13 separate bills, is set to be agreed by today (Thursday).

Colln Macilwain

\title{
French gene laboratory gets a new lease of life
}

Paris. Uncertainty over the future of the Généthon laboratory near Paris has ended, following a decision by the French Muscular Dystrophy Association (AFM) to launch two long-term research programmes, one to identify disease genes, the other to work out what they do, and how.

Généthon was set up in 1990 jointly by AFM and the Centre d'Etudes du Polymorphisme Humain (CEPH). It is based at AFM's headquarters at Evry near Paris, and has built a reputation as one of Europe's most advanced gene mapping centres.

Earlier this year, however, AFM announced that it would not support further long-term research programmes after Généthon completed its mapping programme this year. It said that it would instead seek to eliminate bottlenecks in gene therapy research by funding research groups and biotechnology companies (see Nature 361, 671; 1993).

Under new plans, to be announced next month, Généthon II will identify genes using the laboratory's physical and genetic maps of the human genome. Its broader aim is to create a centre of excellence to develop improved positional cloning techniques to be made available to research groups worldwide. The programme will be headed by Jean Weissenbach, who published a 'second generation' genetic map of the human genome last year (see Nature 359, 380; 1992).

Axel Kahn, director of the INSERM Laboratory on Genetics and Molecular Pathology at the Cochin Institute of Molecular Genetics in Paris, will lead Généthon III. This will work out the role and function of genes once they have been identified. In particular, it will test what happens when genes of unknown function are inserted into mice, develop less-empirical ways of assessing gene function, and create animal models for particular diseases

Généthon II will begin immediately. The start of Généthon III will depend on whether AFM reaches its target of FF400 million

(US\$71 million) in a television appeal in December (last year it raised FF314 million in this way). AFM plans eventually to back research on vectors for gene therapy (Généthon IV) and clinical trials (Généthon V).

Bernard Barateau, the president of AFM, says that several companies, including Rhône-Poulenc Rorer, are planning to invest in Généthon II and III. The local authority has also made available to AFM land next to Généthon to help it attract biotechnology companies and other research groups to the site.

Private organizations and charities contribute significantly to the French genome effort. The government is keen to integrate such organizations into its national strategy for genome research. François Fillon, the minister of higher education and research, is said to be impressed by Généthon's approach; Kahn says he has also expressed an interest in funding AFM's new programmes directly.

But although GREG funds some research at Généthon, close collaboration between the government-backed programme and AFM has been blocked by a long-standing deadlock between Barateau and Piotr Slominski, the director of GREG. One solution may be that proposed by Fillon to appoint one research organization to take responsibility for co-ordinating each area of biological research.

It is not known if Fillon intends to include genome research in this scheme. But François Kourilsky, director general of the Centre National de la Recherche Scientifique (CNRS), says that CNRS could become the lead agency for genome research. If this were accepted, he says, he would bring together the opposing parties by "imposing fortnightly meetings".

Meanwhile, Slominski is taking comfort from the fact that Fillon has increased GREG's budget for next year. "This clearly shows his willingness to develop genome research", he says.

Declan Butler

\section{Bid to launch 'European PhD'}

London. Scientists from the 12 member states of the European Communites (EC), as well as four non-EC European states, have set up an executive board to oversee the development of a European doctorate in biotechnology. A meeting in Luxembourg last week discussed how the new doctorate could be awarded to those completing a $\mathrm{PhD}$ programme recognized throughout Europe, and was told that it might form a prototype for similar programmes in other disciplines.
The initiative has been backed by Antonio Ruberti, the European Commissioner for research, who told the Luxembourg meeting that it was in line with the commission's attempts to increase the mobility of doctoral and postdoctoral fellows within the EC. In addition to the 12-member executive board, the development of the new doctorate will also come under the scrutiny of six scientific trustees, including Nobel laureates Renato Dulbecco and Werner Arber. 